\title{
EFEITO DE CHOQUE TÉRMICO NA EXPRESSÃO DE SINTOMAS DA SOROSE DOS CITROS EM QUATRO LARANJAS DOCES INDICADORAS
}

\author{
NIVALDO GUIRADO \\ Engenheiro Agrónomo
}

Orientador: Dr. Gerd Walter Müller

\begin{abstract}
Dissertação apresentada a Escola Superior de Agricultura "Luiz de Queiroz"., da Universidade de São Paulo, para obtenção do grau de Mestre em Agronomia, Area de Concentracão: Fitopatologia.
\end{abstract}

PIRACICABA

Estado de São Paulo - Brasil

Agosto - 1992 
Ficha catalográfica preparada pela Seção de Livros da Divisão de Biblioteca e Documentação-PCARP/U5P

Guirado, Nivaldo

G965e Efeito de choque térmico na expressão de sintamas da so rose dos citros em quatro laranjas doces indicadoras. Pi racicaba, 1992.

59p. ilus.

Diss. (Mestre) - ESALQ

Bibliografia.

1. Laranja - Doença 2. Sorose dos citros - Sintoma - E feito de choque térmico 3. Virus fitopatogênico I. Escola Superior de Agricultura Luiz de Queiroz, Piracicaba

CDD $\quad 632.8$

634.31 


\section{EFEITO DE CHOQUE TERMICO NA EXPRESSZO DE SINTOMAS DA SOROSE DOS CITROS EM QUATRO LARANJAS DOCES INDICADORAS}

NIVALDO GUIRADO

Aprovado em: 09/10/92

Comissão julgadora:

Prof. Dr Hiroshi Kimati

ESALQ/USP

Dr. Gerd Walter Müller IAC-Campinas

Dr. Hugo Kuniyuki IAC-Campinas

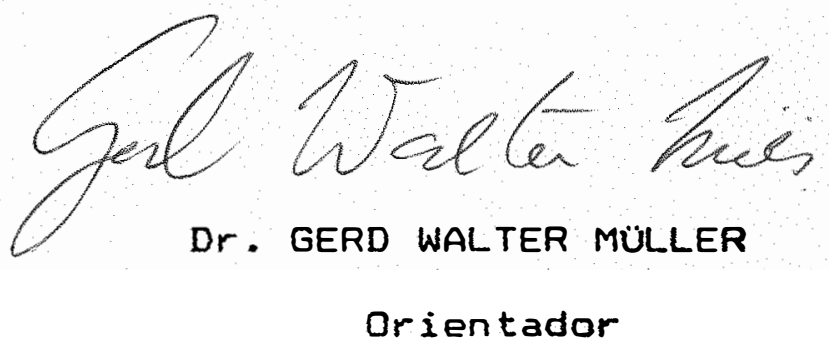


A minha esposa Cecilia

Aos meus filhos Gustavo e Gisele

pelo amor, estímulo e compreensao

DEDICO. 


\section{AGRADECIMENTOS}

- Ao Sr. Dr. Gerd Walter Müller, pela orientaçăo no desenvolvimento deste trabalho.

- Aos Srs. Drs. Alvaro Santos Costa e Jorge Alberto Marques Rezende pelas sugestres.

- Ao Horto Florestal de Limeira, em especial ao Dr. Ariovaldo Greve, Dr. Valmir Prada e Dr. João Jose Carcaioli pelas facilidades propiciadas na realizaçăo deste trabaltio.

- Ao amigo Marco Galli pelo incentivo e apoio.

- Aos amigos José Luiz Silverio e Sr. Andréas Savióli pelos cuidados com as plantas.

- Ao Sr. Dr. Joaquim Téfilo Sobrinho pelo formecimento de sementes e borbulhas indicadoras.

- Aos colegas e funcionários da Seção de Virologia pela ajuda e estímulo.

- Ao ex-Diretor Geral do Instituto Agronómico Dr. Oriovaldo Brunini, por nos permitir participar do Curso de Mestrado em Fitopatologia.

- Áminha esposa e filhos pelo amor e incentivo.

- A todos aqueles que direta ou indiretamente participaram do desenvolvimento deste trabalho, agradeço. 


\section{SUMARIO}

Página

LISTA DE FIGURAS ................... viii

LISTA DE TABELAS ..................... ix

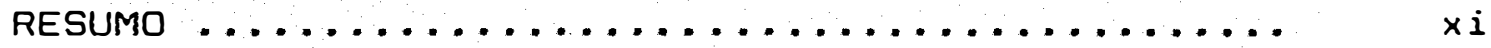

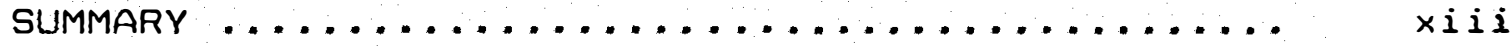

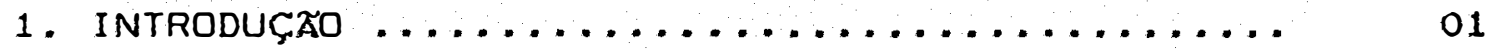

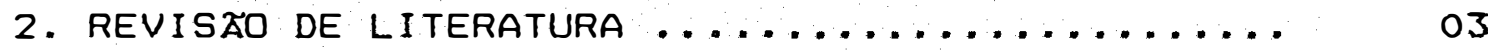

2.1. Trabaltios pioneiros .................. 03

2.2. Distribuição geográfica e importancia eco-

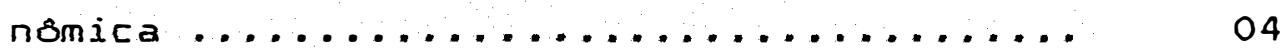

2.3. Sintomatologia ................... os

2.4. Agente causal .................. ob

2.5. Transmissăo e epidemiologia ........... 07

2.6. Diegnose ........................ o8

3. material e metodos ...................... 15

3.1. Obtenção do porta-enxerto ............. 15

3.2. Fonte de inoculo ................. 18

3.3. Indicadoras ..................... 18

3.4. Coleta e transporte das fontes de inóculo e indicadoras ...................... 19

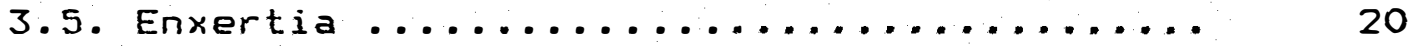

3.6. Exposição das plantas a diferentes tempe-

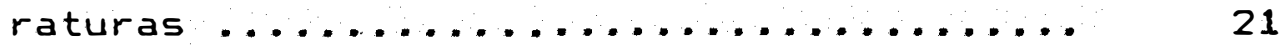

3.7 . Avaliação ...................... 25

4. RESUltados ............................. 27

4.1. Laranja Baianinha inoculada com duas fon-

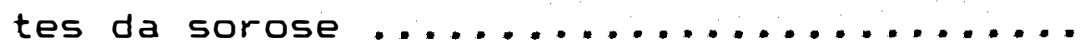


4.1.1. Submetida à temperatura de $15 \circ \mathrm{C} \ldots .27$

4.1.2. Submetida a temperatura de $20 \circ \mathrm{C} \ldots 28$

4.1.3. Submetida à temperatura de $25^{\circ} \mathrm{C} \ldots .33$

4.1.4. Mantida em temperatura ambiente ... 33

4.2. Laranja do Céu inoculada com duas fontes



4.2.1. Submetida à temperatura de $15 \circ \mathrm{C} \ldots .34$

4.2.2. Submetida a temperatura de $200 \mathrm{C} \ldots . .35$

4.2.3. Submetida à temperatura de $25^{\circ} \mathrm{C} \ldots 36$

4.2.4. Mantida em temperatura ambiente... 36

4.3. Laranja Madame Vinous inoculada com duas fontes da sorose .................. 37

4.3.1. Submetida à temperatura de $15^{\circ} \mathrm{C} \ldots . .37$

4.3.2. Submetida à temperatura de $200 \mathrm{C} \ldots . .38$

4.3.3. Submetida à temperatura de $25^{\circ} \mathrm{C} \ldots . .38$

4.3.4. Mantida em temperatura ambiente ... 39

4.4. Laranja Baianinha enxertada com borbulhas de quatro laranjas doces suspeitas de estarem infectadas pela sorose ........... 39

4.4.1. Submetida a temperatura de $15^{\circ} \mathrm{C} \ldots 39$

4.4.2. Mantida em temperatura ambiente... 43

4.5. Laranja do Céu enxertada com borbulhas de quatro laranjas doces suspeitas de estarem infectadas pela sorose ............... 43

4.5.1. Submetida à temperatura de $15 \circ \mathrm{C} \ldots . .43$

4.5.2. Mantida em temperatura ambiente... 44

4.6. Laranja Madame Vinous enxertadas com borbulhas de quatro laranjas doces suspeitas de estarem infectadas pela sorose ....... 44

4.6.1. Submetida à temperatura de $15^{\circ} \mathrm{C}$... 44

4.6.2. Mantida em temperatura ambiente ... 45 
Página

4.7. Laranja Caipira enxertada com borbulhas de quatro laranjas doces suspeitas de estarem

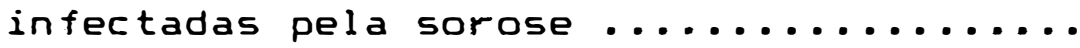

4.7.1. Submetida a temperatura de $150 \mathrm{C} \ldots . .45$

4.7.2. Mantida em temperatura ambiente $\therefore \quad 46$

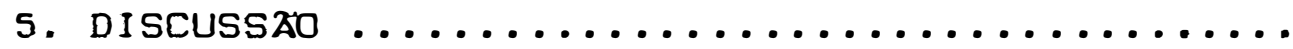

6. CONCLUSOES ........................ 


\section{LISTA DE FIGURAS}

FIGURA N•

Página

01 Plantas utilizadas nos experimentos. A Em vaso de barro. 8 - Em saco plástico.

02 Camara de crescimento utilizada para indução de sintomas da sorose ........

03 Folhas de laranja doce mostrando intensidades variáveis de sintomas da sorose. A - Folha sadia. B. Sintoma fraco. C - Sintoma médio. D - Sintoma forte $\ldots \ldots \ldots \ldots \ldots \ldots \ldots \ldots \ldots \ldots \ldots$ 


\section{LISTA DE TABELAS}

TABELA N•

Página

01 Efeito de diferentes temperaturas na manifestação e intensidade de sintomas da sorose na primeira brotação de trés indicadoras de laranja doce inoculadas com duas fontes do virus ................

02 Efeito de diferentes temperaturas na manifestação de sintomas da sorose na segunda brotação de três indicadoras de laranja doce inoculadas com duas fontes

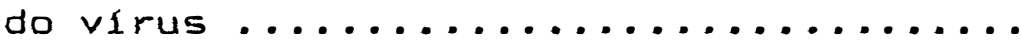

o3 Número médio de dias entre o inlcio do tratamento térmico e o aparecimento de sintomas da sorose na primeira brotaçăo de tros indicadoras de laranja doce inoculadas com duas fontes do virus após exposição ds temperaturas indicadas ....

04 Número médio de dias entre o infcio do tratamento térmico e o aparecimento de sintomas da sorose na segunda brotação de três indicadoras de laranja doce inoculadas com duas fontes do vírus, após exposição às temperaturas indicadas ....

05 Efeito do choque térmico na manifestação de sintomas da sorose em quatro indicadoras de laranja doce enxertadas com borbulhas de quatro plantas suspeitas de estarem infetadas com este vírus ...... 
O6 Efeito de choque térmico na intensidade de sintomas da sorose em quatro indicadoras de laranja doce enxertadas com borbulhas de quatro plantas suspeitas de estarem infetadas com este virus .......

07 Número médio de dias entre 0 inflcio do tratamento térmico e o aparecimento de sintomas da sorose em quatro indicadoras de laranja doce enxertadas com borbulhas de quatro plantas, suspeitas de estarem infetadas com este virus, submetidas a choque termico .................. 


\section{EFEITO DE CHOQUE TERMICO NA EXPRESST̃O DE SINTOMAS \\ DA SOROSE DOS CITROS EM QUATRO LARANJAS DOCES INDICADORAS}

Autor: NIVALDO GUIRADO

Orientador: Dr. GERD WALTER MÜLLER

\section{RESUMO}

Os testes de indexaçăo biológica para a sorose dos citros estão baseados em sintomas foliares espec1ficos. Em Săo Paulo, estes testes são limitados pela ocorrencia de alta temperatura que prevalece na maior parte do ano, e, devido a este fato, sintomas so podiam ser observados durante a brotaçăo da primavera com temperatura amena $\left( \pm 20^{\circ} \mathrm{C}\right)$.

Visando determinar a possibilidade de que os sintomas da sorose pudessem vir a ser expressados também nos perídos quentes do ano, foram realizados dois experimentos. No primeiro utilizou-se plantas indicadoras de laranjas doces (Citrus sinensis (L.) Osbeck) das variedades Baianinha', 'do Céu' e 'Madame Vinous' enxertadas sobre limåo 'cravo' (Citrus limonia (L.) Osbeck) e inoculadas com isolados do virus da sorose procedentes das laranjas doces 'Natal' e 'Folha Murcha'. As plantas foram formadas em casa-de-vegetação a 30.C, al permanecendo até que apresentassem em seu ramo de 3 a 4 folhas com 3 a 4 cm de 
comprimento, sendo nesta fase transferidas para câmaras de crescimento com luminosidade igual e constante, 16 horas por dia fornecida por 8 lámpadas 40 de 85 Watts cada tipo luz do dia e 5 låmpadas incandescentes de 40 Watts cada. A temperatura das cåmaras foi regulada para $15 \cdot \mathrm{C}, 20 \cdot \mathrm{C}$ e $25 \cdot \mathrm{C}$. observou-se que o choque térmico a $15{ }^{\circ} \mathrm{C}$ por 3 a 6 dias proporcionou a melhor expressão sintomatológica da sorose; que as CVS 'Baianinha' $e$ 'do Cêu' são melhores indicadoras do que a 'Madame Vinous'; e que a procedencia do virus influi na severidade dos sintomas.

No segundo experimento, foram empregadas as laranjas doces 'Baianinha', 'do Céu', 'Madame Vinous' e 'Caipira', que foi indicadora padrão em São Paulo. Essas indicadoras foram preparadas de maneira semelhante do primeiro experimento, enxertadas com borbulhas de plantas de laranja 'Pera', 'Natal', 'Valencia' e 'Hamlin' suspeitas de estarem infetadas pelo vírus da sorose e submetidas a choque térmico de $15 \circ \mathrm{C}$. Os resultados obtidos indicaram também nesse caso que o choque térmico de $15 \cdot \mathrm{C}$ por 3 a 6 dias comprovou ser o mais adequado para a expressão sintomatológica da sorose; que as laranjas 'Baianinha' e 'do Céu' se mostraram mais eficientes do que a 'Madame Vinous' a 'Caipira'; que das 4 laranjas doces suspeitas, apenas a 'Valencia' achava-se infetada pelo virus, estando as demais ('Pera', 'Natal' e 'Hamlin') sadias. 
THERMAL SHOCK EFFECT ON PSOROSIS SYMPTOMS EXPRESSION

IN FOUR SWEET ORANGE INDICATORS

Author: NIVALDO GUIRADO

Adviser: Dr. GERD WALTER MÜLLER

\section{SUMMARY}

Biological indexing for citrus psorosis is based on particular foliar symptoms. In the State of Såo Paulo, the indexing is limited by the occurrence of high temperatures during the most part of the year, and, because of this, the symptoms can only be seen during the spring growth flush when mean temperatures are around $20 \circ \mathrm{C}$.

In order to induce psorosis symptoms on the indicator plants during the warm periods, two experiments were carried out. The indicator plants for the first experiment were sweet oranges (Citrus sinensis (L.) Osbeck) cv. 'Baianinha', 'do Céu' and 'Madame Vinous', grafted on lime (Citrus limonia (L.) Osbeck) cv 'Rangpur'. These plants were graft inoculated with psorosis infected buds collected from 'Natal' and 'Folha Murcha' sweet oranges. The plants were kept under greenhouse conditions (average temperature of $30^{\circ} \mathrm{C}$ ) until they had developed 3-4 leaves with 3-4 cm long. The plants were then transferred to growth chambers with 16 hours of light and temperatures 
adjusted to $15 \circ \mathrm{C}, 20 \circ \mathrm{C}$ and $25 \circ \mathrm{C}$, respectively. Light was supplied by 8 HO lamps of 85 watts and 5 incandescent lamps of 40 watts. It was observed that plants exposed to $15 \circ \mathrm{C}$ for 3-6 days showed the best symptoms of psorosis and that 'Baianinha' and 'do Céu' sweet oranges were better indicator for psorosis than 'Madame Vinous'. Also, the origin of the psorosis virus isolate affected the severity of the symptoms.

For the second experiment the same indicator plants mentioned above were used with addition of the 'Caipira' sweet orange which was the standard indicator plant for psorosis in Săo Paulo. The plants were prepared as described before. Buds from 'Pera', 'Natal', 'Valencia', and Hamlin sweet oranges suspected to be infected by psorosis virus were used as source of inoculum. Plants were placed in a growth chamber at $15^{\circ} \mathrm{C}$ and.same luminosity as in the first experiment. The results of this experiment confirmed that the thermal shock at $15^{\circ} \mathrm{C}$ for 3 to 6 days was the most adequate for symptoms expression of psorosis. It was also observed that 'Baianinha' and 'do Céu' sweet oranges were better indicator for psorosis than Madame Vinous', and 'Caipira' sweet oranges. Among the four sweet oranges suspected to be infected by psorosis virus, only 'Valencia' was found infected. 


\section{INTRODUÇÃO}

Testes de indexação são imprescindıveis para evidenciar a presença ou ausência de virus conhecidos em plantas suspeitas. Para tal, os testes biológicos, através de plantas indicadoras são bastante usados no Estado de São Paulo. A maioria deles está baseada em sintomas foliares especificos induzidos pelos vários vírus, sendo verdadeiro também no caso das viroses dos citros. FAWCETT (1934) foi o primeiro pesquisador a associar sintomas foliares aos diversos sintomas verificados no tronco das variedades citricas agrupados com o nome de sorose.

No Brasil, trabalhos inicialmente realizados para detectar a presença do vírus da sorose, utilizaram a laranjeira 'Caipira' (Citrus sinensis (L.) Osbeck) enxertada sobre limão 'Cravo' (Citrus limonia (L.) Osbeck) como indicadora para detectar sintomas foliares. GUIRADO et alii (1986b) visando determinar o comportamento de diversos tipos de citros em relação a laranja 'Caipira' como indicadora para a sorose, apontam as laranjas doces 'Baianinha' e 'Jo 
Céu' (Citrus sinensis (L.) Osbeck) como indicadoras mais sensiveis do que a laranja 'Caipira' para este virus.

o teste de indexação para a sorose, nas condiçơes de Săo Paulo, tem o inconveniente de ser. limitado pela ocorréncia de altas temperaturas na maior parte do ano, uma vez que no Estado os sintomas nas folhas das plantas indicadoras somente podem ser observados na brotação de primavera, quando a temperatura esta mais amena ( $\left.\pm 20^{\circ}\right)$. Caso isto não ocorra, torna-se necessário aguardar a proxima primavera para observar sintomas.

Visando contornar essa dificuldade, procurou-se desenvolver uma técnica para que sintomas também fossem obtidos nos periodos quentes que abrangem a maior parte do ano. Tal foi conseguido atraves de um trabalho preliminar de choque térmico, sendo os resultados bastante promissores (GUIRADO et alii, 1986a). Visando aprimorar esta linha de pesquisa, foi desenvolvido o presente trabalho, o qual teve como objetivos: A) determinar em que condições de temperatura as plantas indicadoras devem ser submetidas para que a expressão máxima dos sintomas venha a ser obtida nos periodos mais quentes do ano; B) aperfeiçoar os testes de indexação biológica através de indicadoras para o vírus da sorose dos citros, visando determinar as mais sensiveis e/ou que apresentem sintomas mais nitidos em menos tempo. 


\title{
2. REVISÃo DE LITERATURA
}

\subsection{Trabalhos pioneiros}

\begin{abstract}
O nome sorose e utilizado para designar um grupo de doenças de virus dos citros, que tem como uma das caracteristicas comuns, produzir sintomas em folhas novas de plantas de qualquer idade. Esse nome foi usado pela primeira vez por SWINGLE \& WEBBER (1896), quando descreveram uma doença, que formava lesठ̌es na casca, conhecida na flórida, Estados Unidos como "gummosis" e na Califórnia como "scaly bark".

FAWCETT (1932) deu o nome de "sorose A" à forma de manifestaçăo mais comum da doença, distinguindo-a da "sorose B", considerada como uma forma severa. Fawcett e colaboradores descreveram ainda, quatro outros tipos ou formas de sorose respectivamente: a gomose cóncava, a sorose alveolar, o encrepamento das folhas e a variegação infecciosa (FAWCETT, 1932; FAWCETT \& BITANCOURT, 1943; FAWCETT \& KLOTZ, 1938; 1939; 1948). Essas doenças, conforme mencionado
\end{abstract}


acima, foram tratadas como um grupo pelas caracteristicas em comum que possuem, no entanto, o encrespamento das folhas e a variegação infecciosa foram mais recentemente, retirados do grupo por serem transmitidas mecanicamente e ter sido identificado um "Ilarvirus" do grupo "Tobacco streak virus" como o responsável por essas doenças (GARNSEY, 1974; CALVERT et alii, 1986; UYEDA \& MINK, 1983).

\section{2. Distribuição geográfica e importåncia econômica}

A sorose foi inicialmente observada na Florida e Califórnia (Estados Unidos), mas, parece ser originária do Oriente, onde está amplamente distribuida, tendose disseminado mundialmente atraves de material de propagação vegetativa (LEE, 1923; FAWCETT, 1936). Depois de ser descrita nos Estados Unidos, a sorose "A" e outras formas da sorose foram descritas ocorrendo em todas as áreas de cultivo de citros do mundo. Em muitas dessas áreas, a sorose foi descrita como principal fator limitante da produção de citros em vários palses (LAROCCA, 1984).

No Brasil, a sorose foi constatada em todos os estados produtores de citros. A primeira menção de sua ocorrencia em nosso pals foi no Estado de São Paulo, por BITANCOURT (1934), que relata té-la visto em pes de laranja Azeda (Citrus aurantium L.). A sorose também foi descrita 
afetando plantas no Estado do Rio de Janeiro e Minas Gerais por FAWCETT et alii (1936). Nos Estados de Pernambuco, Bahia, Săo Paulo e Rio Grande do Sul por FAwCETT \& BITANCOURT (1937).

\title{
2. 3. Sintomatologia
}

\begin{abstract}
Os sintomas foliares ocorrem em plantas de citros de qualquer idade, infectadas com qualquer uma das formas consideradas associadas a sorose. Aparecem sintomas durante o fluxo de crescimento, que podem variar grandemente em extensăo e intensidade em plantas individuais num determinado período.
\end{abstract}

FAWCETT (1933) foi guem descreveu pela primeira vez os sintomas foliares da sorose, tendo-se aprofundado posteriormente no assunto (FAWCETT \& BITANCOURT, 1943; FAWCETT \& KLOTZ, 1938; 1939, 1948; WALLACE, 1945; 1957). Os sintomas foram descritos como pequenas áreas cloroticas alongadas, de cor verde mais claro que a folha, paralelas às nervuras secundárias que săo mais facilmente visiveis contra a luz. As áreas cloroticas podem ocorrer sobre toda a folha ou então somente em parte desta. Ás vezes, a maioria das folhas de mesmo tamanho mostram os sintomas, em outras ocasioes no entanto, relativamente poucas folhas săo afetadas. Folhas novas, de árvores infetadas 
com a forma de sorose conhecida como gomose cóncava, apresentam outro tipo de mancha clorótica, com a forma dos contornos da folha de carvalho.

Em palses de clima quente como é o caso do Brasil, os sintomas somente são vislveis nas folhas novas, próximas à completa expansăo, na brotaçăo de primavera, quando a temperatura fica mais amena. Os sintomas foliares gradativamente desaparecem, à medida que as folhas amadurecem.

\subsection{Agente causal}

O agente causal da sorose e doenças associadas como sendo deste grupo, ainda não foi totalmente caracterizado, mas há evidências de que seja de natureza viral.

GARCIA et alii (1991), estudando a sorose dos citros na Argentina, verificaram que a moléstia estava associada à particulas de um virus bipartite cujo material genético é representado por uma fita simples de RNA. Observaram ainda que a infectividade do agente causador da sorose estava associada ao material genético e a uma protelna estrutural de $50 \mathrm{KDa}$

LEVY \& GUMPF (1991) na Califórnia, Estados Unidos, estudando um isolado de sorose A, verificaram ser o 
agente causal, um virus alongado, medindo 660-665 x $12 \mathrm{~nm}$. Devido a diversas semelhanças entre as particulas do virus estudado e aquelas dos Carlavirus os autores levantaram a possibilidade de ser o virus da sorose um membro desse grupo.

\subsection{Transmissão e epidemiologia}

A sorose é transmitida normalmente por união de tecidos, tendo sido FAWCETT (1933) o primeiro pesquisador a demonstrar sua natureza transmissivel. A sorose "B" já foi transmitida mecanicamente. Transmissão da gomose côncava através da semente já foi descrita em citrange 'Carrizo' (Poncirus trifoliata (L.) Raf. $x$ Citrus sinensis (L.) Osbeck) por BRIDGES et alii (1965),. Citrange 'Troyer' (Poncirus trifoliata (L.) Raf. X Citrus sinensis (L.) Osbeck) por PUJOL (1966) e em 'Trifoliata' (Poncirus trifoliata (L.) Raf.) por CAMPIGLIA et alii (1976). A disseminaçăo natural da sorose no campo foi relatada em Concordia na Argentina por BENATENA \& PORTILLO (1984), e por PASSOS et alii (1974) na Bahia - Brasil havendo suspeita de posslveis vetores. 


\subsection{Diagnose}

A condição climática é de fundamental importância na expressão de sintomas para o virus da sorose. No Brasil, a dificuldade em se observar sintomas nas folhas novas das indicadoras, está diretamente relacionada à temperatura, que no verão chega a atingir $\pm 40 \circ \mathrm{C}$ por várias horas do dia, principalmente em casas de vegetação e telados. Temperaturas contı́nuas desta ordem são suficientes para inativar o virus da sorose, ou ainda, evitar o estabelecimento do virus em tecidos jovens, ainda que o mesmo esteja estabelecido em tecidos mais velhos conforme foi demonstrado por GRANT (1957).

FAWCETT \& BITANCOURT (1937) mencionaram a sorose como a doença dos citros mais importante do Estado da Bahia, Brasil. Esses autores observaram que, embora existentes, os sintomas nas folhas novas eram diflceis de serem encontrados, sugerindo que o fato era devido à temperatura mais elevada, própria da região. A ausência de sintomas foliares tipicos da sorose da Bahia foi também verificada por PASSOS (1965), que não conseguiu observar sintomas, seja em brotaçōes novas de árvores adultas de laranjeira 'Bahia' e 'Pera' (Citrus sinensis (L.) Osbeck) que apresentavam sintomas tipicos de sorose da casca, que tinham sido podadas para forçar a brotação, ou em brotaçơes de gemas de laranja 'do Céu', enxertadas em diversos cavalos, originários de 
plantas existentes na Estação Experimental "Sylvio Moreira" do IAC - São Paulo, que mostraram consplcuos sintomas foliares nessa última.

No Estado de São Paulo, GuIRADo et alii (1986a) enfrentando dificuldades para obter sintomas de sorose nas folthas da indicadora laranja 'do Céu' devido a elevada temperatura prevalente durante o verão neste Estado, trabalharam com plantas infetadas da indicadora acima citada, sendo um grupo de plantas mantido em casa de vegetação e um outro colocado em uma sala com temperatura constante de $20^{\circ} \mathrm{C}$ e sob 10 horas de iluminação diaria, fornecida por 2 lámpadas fluorescentes de 40W, do tipo luz do dia, situadas no teto, à cerca de 3 metros das plantas. Após 2 dias, uma das plantas apresentou áreas clorsticas alongadas, de cor verde claro, paralelas às nervuras secundarias, caracteristicas da virose. Cinco dias após o infcio do tratamento, as demais plantas infetadas apresentaram fortes sintomas foliares, conforme descrito acima e lintias cloroticas formando desentios do tipo foltha de carvaliho. As plantas infetadas que permaneceram na casa de vegetação, bem como os controles sadios, não exibiram sintomas.

Na Venezuela, Malagut i \& STONER (1954) observaram a presença de sintomas associados ao virus da sorose em condiçăes de campo. No entanto tentanto induzir sintomas em indicadoras MALAGUTI \& KNORR (1961) concluiram que nåo haviam evidencias para confirmar a presença da soro- 
se nas plantaçơs citricolas da Venezuela, ou mesmo através de estudos de transmissão em casa de vegetação utilizando a laranja doce como indicadora.

$$
\text { CALAVAN et alii (1978) explicaram que as }
$$

dificuldades encontradas na Venezuela para obtençăo de sintomas da sorose se deve ao clima tropical, cuja temperatura é inadequada para a manifestação de sintomas, além disso, as casas de vegetação utilizadas nesse pals foram desentiadas para regiós de outras latitudes, não sendo, portanto, adequadas para os testes de diagnose da sorose.

MONTEVERDE et alii (1980), visando determinar a presença do virus da sorose nas plantaçðes citricolas da Venezuela, inocularam seedlings de laranja doce cv. 'Hamlin. (Citrus sinensis (L.) Osbeck) a partir de uma arvore da laranja doce cV. 'Washington Navel' (Citrus sinensis (L.) Osbeck), suspeita de estar infetada com o vírus da sorose. As plantas após a inoculação foram colocadas em uma câmara de crescimento iluminada com tubos fluorescentes tipo GroLux a $156 \mathrm{~W} / \mathrm{m}^{2}$, a uma temperatura de $19 \pm 0,5^{\circ} \mathrm{C}$ e umidade relativa de $70-90 \%$. Na sexta semana após a inoculação, $20 \%$ das plantas indicadoras mostraram sintomas positivos e na décima semana $90 \%$ das plantas mostraram sintomas, confirmando experimentalmente pela primeira vez a presença do vírus da sorose na Venezuela. 
Outros autores relataram em seus trabalhos a importåncia da temperatura na manifestação de sintomas da sorose. Nos Estados Unidos, WALLACE (1945) descreveu que, para deteç̧ăo do virus da sorose no campo, nas regizes subtropicais, a leitura dos sintomas deve ser feita durante a brotação de primavera, quando ocorrem as temperaturas baixas favoráveis a indução de sintomas.

ROISTACHER (1976), descreve que a temperatura nas quais as plantas estão se desenvolvendo, tem um efeito muito significativo na expressão de sintomas de viroses. Classifica as manifestaçß̋es dos sintomas das viroses dos citros como condicionadas por temperaturas altas e baixas, enquadrando nesta última, a sorose $A$ e a gomose cóncava. Este autor, trabalhando com estas duas viroses, inoculou segdisng de 'tangor Dweet' e laranja doce'pineapple' com dois isolados de sorose $A$ e um de gomose cóncava, colocandoas temperatura de $38 / 24 \circ \mathrm{C}$. A expressão de sintoma foliar de sorose A no primeiro fluxo de crescimento foi suprimida nas temperaturas mais quentes e os sintomas de gomose côncava não se manifestaram, enquanto que, nas temperaturas mais frias, as plantas apresentaram sintomas sendo que somente um tangor 'Dweet' produziu melhores sintomas na temperatura quente. Segundo este mesmo autor, as temperaturas nas quais as plantas são submetidas para expressão de sintomas săo muito importantes para a diagnose. Assim, os sintomas da tristeza, sorose A, gomose côncava, variegaçăo infecciosa, 
nanismo da satsuma e enação foliar, são mais acentuados em temperatura baixa, enquanto que os sintomas da exocorte e xiloporose se manifestam melhor em temperatura mais elevada. Por estas razôes, o uso de casa de vegetação om um único ambiente para detectar os diversos patógenos dos citros, não é recomendado.

Além da temperatura adequada para a manifestação de sintomas da sorose dos citros, a escolha da planta indicadora é de fundamental importåncia. No entanto, poucos foram os estudos visando selecionar indicadoras que dessem sintomas mais nitidos em menor tempo. Na maioria dos casos, as plantas escolinidas para os testes de indexaçăo são aquelas que apresentam alguns sintomas foliares em condiçত̃es de campo.

Nos Estados Unidos, ROISTACHER \& NAUER (1964) compararam dez variedades de laranja doce e uma tangerina como plantas indicadoras para a sorose "A" e duas estirpes de gomose cóncava. A laranja doce 'Pineapple' foi considerada a melhor indicadora, seguida pela 'Madame Vinous', 'Olivelands' e 'Parson Brown', também variedades de laranja doce, que exibiram sintomas nitidos para a Sorose "A" e para a estirpe Californiana de Gomose Côncava. Nove das dez variedades de laranja doce testadas foram satisfatórias para detectar uma estirpe muito branda de Gomose Cóncava, enquanto que a tangerina 'King' inoculada com esta estirpe mostrou sintomas tipo "folha de carvalho". As variedades de 
laranja doce 'Mediterranean' e 'Dillar' foram consideradas como indicadoras pouco sensiveis para os virus testados.

CHIARAPPA (1966) escreveu sobre as principais plantas indicadoras utilizadas para testes, de indexação no mundo, separando-as por palses e instituiçăes de pesquisa. Para o teste de indexação biológica para a sorose, as indicadoras mais utilizadas são as do grupo das laranjas doces, e entre elas a 'Madame Vinous', 'Pineapple', 'Koethen' e 'Hamlin' săo as mais utilizadas.

WALLACE (1958), ROISTACHER \& BLUE (1968), nOS Estados Unidos, descreveram as tangerinas e hibridos de tangerinas como as melhores indicadoras para o virus da sorose, devido essas variedades terem apresentado sintomas caracterssticos da sorose quando inoculadas com estirpes fracas deste virus.

CALAVAN et alii (1978) citam as tangerinas 'Kara', 'King' e 'Dancy' como boas indicadoras para o virus da sorose e doenças deste grupo e consideram o tangor 'Dweet', como a indicadora mais sensivel.

No Brasil, GUIRADO et alii (1986b) compararam sete variedades de laranjas doces (Citrus sinensis (L.) Osbeck) e duas tangerinas (Citrus reticulata, Blanco), incluindo como padrăo a laranja doce 'Caipira', utilizada nos testes de indexação para matrizes de citros no Estado de São Paulo. Os resultados "obtidos mostraram sintomas evidentes e característicos da doença nas laranjas doces 
'Baianinha' e 'do Céu'; sintomas fracos nas laranjas doces 'Hamlin', 'Pineapple' e 'Caipira'; ja a laranja 'Azeda' e as tangerinas 'Kara' e 'King' não exibiram sintomas. 


\section{MATERIAL E MÉTODOS}

Os experimentos para avaliar o efeito das diferentes temperaturas na manifestação de sintomas do víus da sorose foram conduzidos na Seção de Virologia Fitotécnica do Instituto Agronómico de Campinas, SP.

\subsection{Obtenção do porta-enxerto}

0 porta-enxerto usado em ambos experimentos foi o limão 'Cravo' (Citrus limonia (L.) Osbeck). Para sua formação, foram coletados frutos de uma única planta da Estação Experimental "Sylvio Moreira", do Instituto Agronómico - Cordeirópolis - SP, dos quais as sementes foram retiradas, lavadas em água corrente, espalhadas sobre folha de jornal e postas para secar à sombra. Uma vez secas, foram tratadas com fungicida à base de PCNB 75\%, na dosagem de 300 9 do produto comercial para $100 \mathrm{~kg}$ de semente. 
Uma parte das sementes (metade) foi semeada em março de 1990, em bandejas de poliestireno expandido (isopor da Eucatex), com 72 cavidades, contendo substrato completo para semeadura a base de vermiculita, matéria orgánica, mais macro e micronutrientes (Plantmax da Eucatex), Após a emergência das plântulas, contando estas com 2 meses de idade, foram transplantadas para vasos de barro com as seguintes dimensðెs: $16 \mathrm{~cm}$ de diåmetro na borda superior, 17 cm de altura e $11 \mathrm{~cm}$ de diåmetro na borda inferior, contendo terra misturada com adubo orgânico de origem animal na proporçăo 3:1. Os porta-enxertos foram conduzidos em casa-devegetaçăo, recebendo tratos culturais e fitossanitários adequados (Figura $1, A)$.

Em maio de 1991 , o restante das sementes foi semeado em tubetes de formato piramidal com capacidade de 50 ml, contendo substrato Plantmax da Eucatex. Após a emergencia das plântulas e contando estas com 2 meses de idade, foram transplantadas para sacos plásticos com as dimensđes de $10 \mathrm{~cm}$ de diåmetro e $19 \mathrm{~cm}$ de altura contendo o mesmo substrato, a fim de facilitar um adequado desenvolvimento do porta-enxerto (Figura $1, B)$. 




Figura 1. Plantas utilizadas nos experimentos. A - Em vaso de barro. B - Em saco plástico. 


\subsection{Fonte de inóculo}

Serviram como fonte de inóculo, plantas da coleção de vírus da Seção de Virologia Fitotécnica do Instituto Agronómico, que em exames anteriores apresentaram nitidos sintomas de sorose. Duas fontes foram escolnidas para este trabalho, devido aos sintomas caracteristicos de sorose que induziram nas folhas novas das plantas indicadoras. Uma foi a laranja 'Natal' (Citrus sinensis (L.) Osbeck), de clone velho com 31 anos de idade, e a segunda foi a laranja 'Folha Murcha' (Citrus sinensis (L.) Osbeck). Para o experimento instalado em maio de 1991 , foram utilizadas borbulhas de quatro plantas de laranja doce, respectivamente 'Pera', 'Valência', 'Natal' e 'Hamlin', de uma coleção de citros mantida na Estaçăo Experimental de Citricultura de Bebedouro, da Fundação de Pesquisa Agroindustrial de Bebedouro, SP, suspeitas de estarem infetadas pelo vírus da sorose.

\section{3. Indicadoras}

Todas as bormulhas das plantas indicadoras selecionadas para o experimento foram coletadas de plantas de clone nucelar existentes na Estaçăo Experimental "Sylvio Moreira" do IAC em Cordeirópolis, SP. 
Para o primeiro experimento, foram escolhidas como indicadoras trés laranjas doces, a saber: 'Baianinha' e 'do Céu' (Citrus sinensis (L.) Osbeck), indicadas por J. Pompeu Jr. (comunicaçăo verbal) e comprovadas experimentalmente por GUIRADO et alii (1986a) como indicadoras bastante senslveis para as nossas condições. A terceira indicadora escoltida foi a laranja 'Madame Vinous' (Citrus sinensis (L.) Osbeck) selecionada por ROISTACHER et alii (1964) e citada por CHIARAPPA (1966), como sendo muito sensivel, e que é normalmente utilizada na indexaçăo da sorose à nivel mundial.

Para o segundo experimento foram utilizadas as 3 indicadoras anteriormente citadas acrescidas da laranja 'Caipira' (Citrus sinensis (L.) Osbeck).

3. 4. Colleta e transporte das fontes de inóculo e indicadoras

Foram coletadas dez estacas ao acaso, ao redor de cada arvore inóculo ou indicadora, situada no campo na Estaçăo Experimental Sylvio Moreira, Cordeirópolis, SP, contendo cada uma delás dez a doze gemas. Para o transporte das estacas da Estaçăo Experimental em questao até a Seçao de Virologia, onde foi realizado o experimento, as mesmas foram acondicionadas em jornal préviamente umidecido em 
água, a fim de protegé-las contra a perda de turgescência e sua consequente inviabilidade, sendo ainda, para uma maior segurança, colocado o jornal contendo os ramos, dentro de um saco plástico e este, em uma caixa de isopor com gelo. Na Seço de Virologia, as borbulhas foram guardadas em geladeira doméstica à $4 \circ C$, dentro de saco plástico, até o momento de serem utilizadas.

\subsection{Enxertia}

A técnica utilizada no preparo das plantas para o teste de indexaça da sorose no primeiro experimento foi a chamada de dupla enxertia, que consistiu em enxertar duas borbulhas do inóculo a $10 \mathrm{~cm}$ acima do colo da planta, e em sentido oposto uma da outra, sendo realizada em dezembro de 1990, quando o porta-enxerto contava com 9 meses de idade e cerca de $1 \mathrm{~cm}$ de diâmetro. Para as indicadoras, utilizouse uma única borbulha por planta, sendo a enxertia efetuada $5 \mathrm{~cm}$ acima dos inóculos, em janeiro de 1991, ou seja, 20 dias após a enxertia dos inóculos, tempo verificado por PRICE (1968), suficiente para que houvesse a invasão do virus nos tecidos da planta. Tanto para os inóculos como também para as indicadoras, as enxertias foram feitas na forma de "T" invertido, onde foram inseridas as borbulhas e em seguida amarradas com fitilho de enxertia, o qual foi 
retirado 20 dias após a enxertia, sendo este tempo o suficiente para que ocorresse união de tecidos (pegamento).

$$
\text { No segundo experimento, foram utilizados }
$$

porta-enxertos com 4 meses de idade (setembro 1991) e com um diámetro em torno de $0,4 \mathrm{~cm}$. A técnica utilizada foi também a de dupla enxertia, através de escudagem embutida, a 5 cm acima docolo da planta, devido ao seu pequeno porte. Simultaneamente foram enxertadas as indicadoras $5 \mathrm{~cm}$ acima dos inoculos, também por escudagem embutida. Após a realização de cada enxertia as borbulhas foram amarradas com fitilho de enxertia, o qual foi retirado 20 dias após.

Todas as plantas do experimento permaneceram em casa-de-vegetação até que as brotaçæes das indicadoras apresentassem de 3 a 4 folhas em fase de expansão com mais ou menos 3 a 4 cm de comprimento sendo nesta fase submetidas as diversas temperaturas para expressão de sintomas.

\subsection{Exposição das plantas à diferentes temperaturas}

Em fevereiro de 1991, quando as indicadoras do primeiro experimento apresentaram a primeira brotação contendo no seu ramo 3 a 4 folhas em fase de expansão, um total de 180 plantas foram submetidas a diferentes temperaturas. Trés grupos de 60 plantas de cada indicadora foram subdivididas em grupos de15 plantas, constituldos respectivamente por 5 plantas inoculadas com isolado procedente da 
laranja 'natal'; 5 plantas com isolado procedente da laranja 'Foliha Murcha' e 5 plantas controles sadios. Quatro diferentes temperaturas foram utilizadas: 15,20 e $25^{\circ} \mathrm{C}$ e ambiente em casa de vegetação.

As temperaturas 15,20 e $25^{\circ} \mathrm{C}$, foram obtidas em cåmaras de crescimento da marca PERCIVAL, modelo PGC-78 com luminosidade igual e constante 16 horas por dia, sendo fornecida por oito lámpadas $H O$ de 85 watts cada, tipo luz do dia e cinco lâmpadas incandescentes de 40 watts cada, as quais ficaram a uma altura de $50 \mathrm{~cm}$ acima das plantas (Figura 2). A temperatura média ambiente variou entre $35,1^{\circ} \mathrm{C}$ (média máxima), $25,2 \circ \mathrm{C}$ (média mlnima) durante a primeira brotação e $33,7 \circ \mathrm{C}$ (média máxima) a $24,3 \circ \mathrm{C}$ (média mínima) na segunda brotaçăo.

As plantas em cámaras de crescimento al permaneceram do dia 22/02/91 ao 01/03/91. Após este periodo, foram retiradas, devido às folhas terem ultrapassado a fase considerada adequada para expressão de sintomas, e entăo retornadas para casa de vegetação onde procedeu-se a poda da copa a fim de estimular uma segunda brotação. Em abril de 1991, quando com nova brotação, as plantas indicadoras foram novamente levadas as câmaras de crescimento para receberem um segundo choque térmico. 


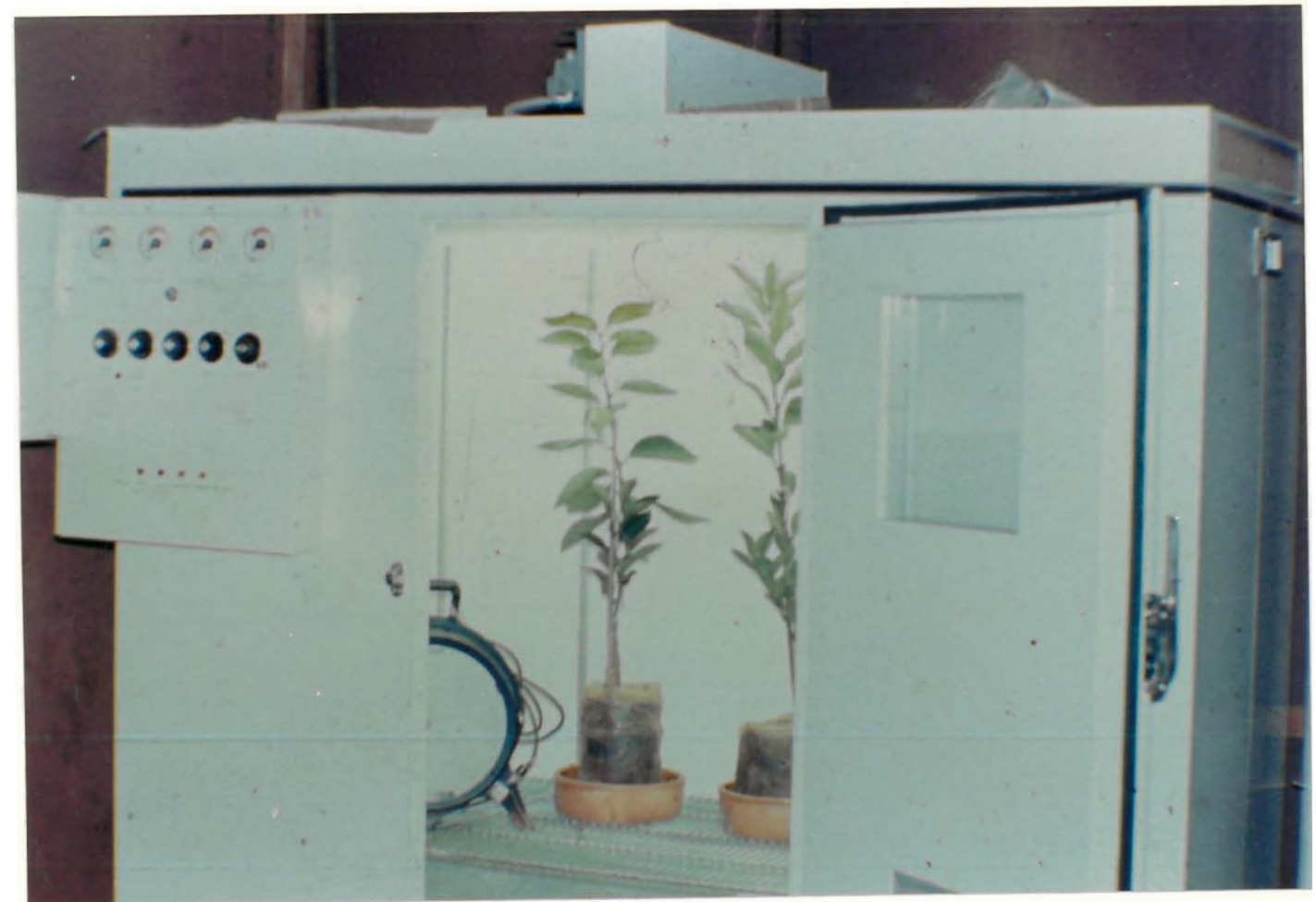

Figura 2. Cămara de crescimento utilizada para indução de sintomas da sorose. 
No segundo experimento, procurou-se verificar a sanidade de quatro plantas dos cultivares: laranja 'Natal', laranja 'Valéncia', laranja 'Pera' e laranja 'Hamlin', mantidas na coleçăo da Estaçăo Experimental de Citricultura de Bebedouro-SP. Para tal, um total de 200 plantas indicadoras de sorose, perfazendo 4 grupos de 50 plantas de cada indicadora (laranja 'do Céu', 'Baianinha', 'Madame Vinous' e 'Caipira') foram divididas em subgrupos de 25 , constituidos respectivamente por cinco plantas enxertadas com borbulhas da planta suspeita laranja'Natal', cinco com laranja 'Pera', cinco com 'Valéncia', cinco com 'Hamlin' e cinco controles sadios. Em outubro de 1991, quando as indicadoras apresentaram a primeira brotação contendo no ramo tres a quatro folhas em fase de expansão, foram submetidas a choque térmico. Neste segundo experimento, duas temperaturas foram empregadas: um grupo de 100 plantas foi submetido à temperatura de $15^{\circ} \mathrm{C}$ e, um outro grupo de 100 plantas, que permaneceu em casa de vegetação, tiveram sua temperatura que variou entre $35^{\circ} \mathrm{C}$ (média máxima) e $23^{\circ} \mathrm{C}$ (média minima) sendo a temperatura média no período de $29^{\circ} \mathrm{C}$. 0 choque térmico à $15^{\circ} \mathrm{C}$ foi obtido com a camara de crescimento, descrita anteriormente. As plantas permaneceram do dia 18 a 29 de outubro de 1991 na camara de crescimento,periodo após o qual foram retiradas, por apresentarem suas folhas com expansão máxima de crescimento. 


\subsection{Avaliação}

Os paråmetros utilizados para determinação do mais adequado teste de indexaçăo biológica para a sorose no presente trabalino basearam-se em: ocorrencia e intensidade de sintomas, temperatura d qual as plantas ficaram expostas, plantas indicadoras, primeira ou segunda brotaçăo das mesmas, isolados do vírus e número de dias para o aparecimento de sintomas. A avaliaçăo foi realizada utilizando-se a seguinte escala de notas: $0=\operatorname{sem}$ sintomas (Figura $3, A)$; 1 = sintoma fraco: representado por folhas que apresentavam áreas cloroticas de cor verde-claro paralelas ds nervuras secundárias, quase imperceptiveis, mesmo quando observadas contra a luz (Figura $3, B$ ); 2 = sintoma medio: representado por folthas que apresentavam áreas cloroticas de cor verdeclaro paralelas as nervuras secundárias, visiveis contra a luz (Figura $3, C$ ); $3=$ sintoma forte: representado por áreas cloroticas de cor verde claro paralelas ds nervuras secundárias facilmente visiveis, mesmo sem serem observados contra a luz (Figura $3, D)$. 


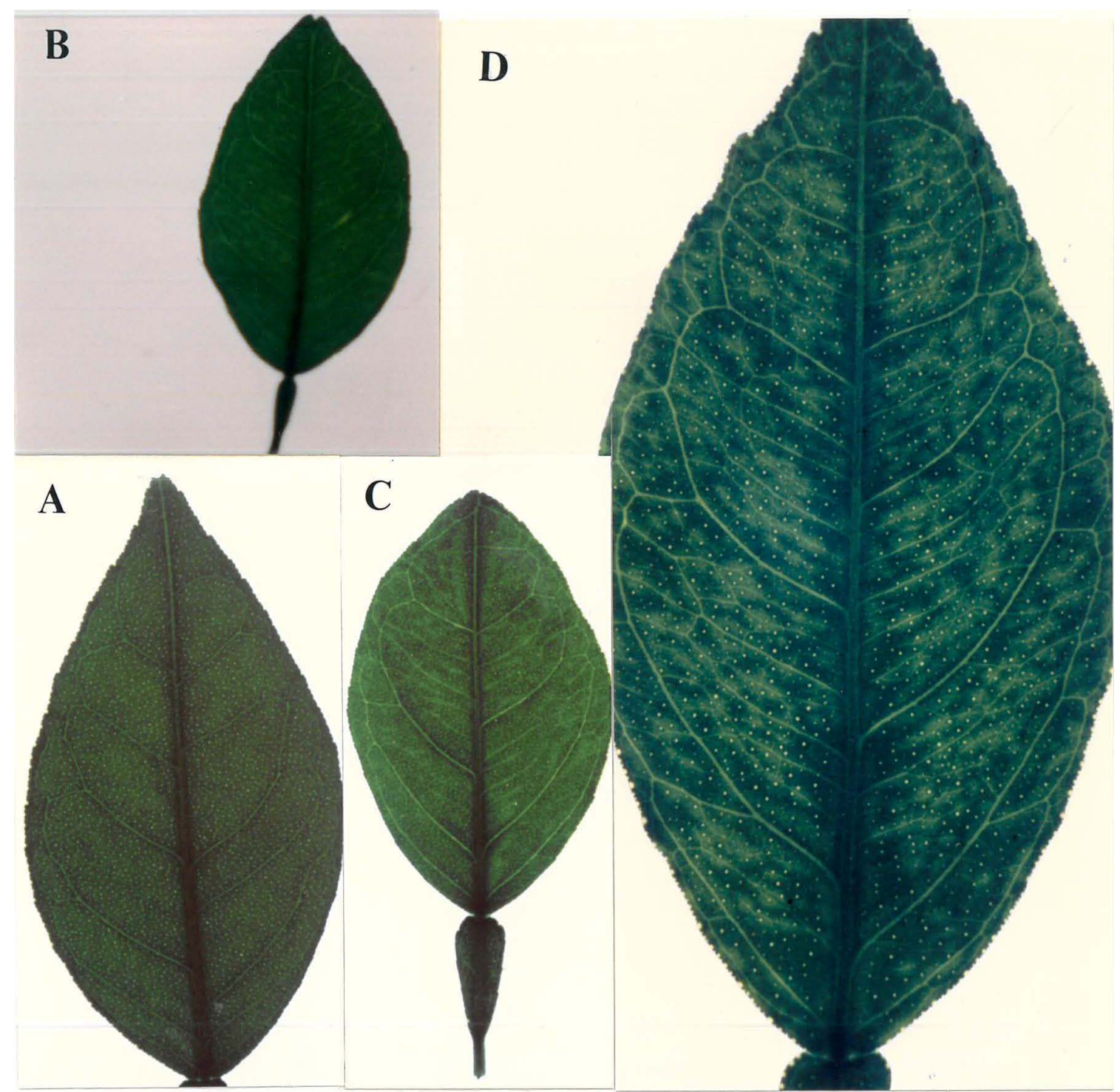

Figura 3. Folhas de laranja doce mostrando intensidades variaveis de sintomas de sorase. A - Folha sadia. B - Sintoma fraco. C - Sintoma médio. D - Sintoma forte. 


\title{
4. RESULTADOS
}

\begin{abstract}
Nas páginas seguintes são apresentados os resultados obtidos no presente trabalino, onde procurou-se avaliar o efeito de diferentes temperaturas, na expressão de sintomas do virus da sorose em folhas de diversas indicadoras.
\end{abstract}

4.1. Laranja 'Baianinha' inoculada com duas fontes da sorose

4.1.1. Submetida à temperatura de $15^{\circ} \mathrm{C}$

A laranja 'Baianinha' utilizada como indicadora apresentou, quando submetida ao choque térmico de $15 \circ \mathrm{C}$, $100 \%$ de plantas com sintomas nas folhas na primeira e segunda brotação, quando inoculadas com isolado procedente da laranja 'Natal' ou 'Folha Murcha' (Tabelas 1 e 2 ). Os controles sadios nåo apresentaram sintomas. Houve pequenas diferenças com esta indicadora quanto a intensidade dos sintomas, que mostraram-se mais acentuado na primeira bro- 
tação do que na segunda, com o inóculo procedente dá laranja 'Folha Murcha' recebendo nota média 2,4 na primeira brotação e 2,0 na segunda, sendo que, com o inóculo da laranja 'Natal', năo houve diferença na intensidade de sintomas entre a primeira e segunda brotação, recebendo nos dois casos, a nota máxima 3. (Tabelas 1 e 2). O número de dias entre o inflcio das exposiçZes térmicas e o aparecimento dos sintomas também variols, sendo de 3 dias com o inóculo procedente da laranja 'Natal' na primeira e segunda brotação e, com o inóculo procedente da laranja 'Folha Murcha', 5 dias na primeira brotação e 4 dias na segunda (Tabelas 3 e 4 ).

\subsubsection{Submetida à temperaiura de $20^{\circ} \mathrm{C}$}

A larania 'Baianinha' quando submetida a temperatura de $20 \circ \mathrm{C}$ também mostrou $100 \%$ de plantas com sintomas tanto na primeira como na segunda brotaçăo com os isolados procedentes das laranjas 'Natal' e 'Folha Murcha' (Tabelas 1 e 2). A nota média dos sintomas foi de 2,2 e 1,8 na primeira brotação com inóculo procedente da laranja 'Natal' e 1,6 e 1,2 para o inóculo procedente da laranja 'Folha Murcha' (Tabelas 1 e 2). O número de dias entre o infcio do tratamento térmico e o aparecimento de sintomas foi de 5 dias da primeira e segunda brotaçăo para os dois inóculos utilizados (Tabelas 3 e 4). Os controles sadios não apresentaram sintomas. 
Tabela 1. Efeito de diferentes temperaturas na manifestaçăo e intensidade de sintomas da sorose na primeira brotação de três indicadoras de laranja doce inoculadas con duas fontes do vírus.

\begin{tabular}{|c|c|c|c|c|c|}
\hline \multirow[b]{2}{*}{ Indicadoras } & \multirow[b]{2}{*}{$\begin{array}{l}\text { Temperatura } \\
\text { de } \\
\text { exposição } \\
\left({ }^{\circ} \mathrm{C}\right)\end{array}$} & \multicolumn{2}{|c|}{ Laranja Natal ${ }^{a}$} & \multicolumn{2}{|c|}{ L. Folha Murcha } \\
\hline & & $\begin{array}{l}\text { No de } \\
\text { plantas } \\
\text { cisint. } \\
\text { inor. }\end{array}$ & $\begin{array}{c}\text { Nota } \\
\text { média } \\
\text { de } \\
\text { sintomas }\end{array}$ & $\begin{array}{l}\text { No de } \\
\text { plantas } \\
\text { c/sint. } \\
\text { inor. }\end{array}$ & $\begin{array}{l}\text { Nota } \\
\text { média } \\
\text { de } \\
\text { sintomas }\end{array}$ \\
\hline L. Baianinta & 15 & $5 / 5$ & 3,0 & $5 / 5$ & 2,4 \\
\hline L. do Céu & 15 & $5 / 5$ & 3,0 & $5 / 5$ & 2,0 \\
\hline L. Madame Vinous & 15 & $5 / 5$ & 2,2 & $4 / 5$ & 1,5 \\
\hline L. Baianinha & 20 & $5 / 5$ & 2,2 & $5 / 5$ & 1,6 \\
\hline L. do Céu & 20 & $4 / 5$ & 2,0 & $4 / 5$ & 1,0 \\
\hline L. Madame Vinous & 20 & $3 / 5$ & 1,0 & $2 / 5$ & 1,0 \\
\hline L. Baianinha & 25 & $3 / 5$ & 1,3 & $2 / 5$ & 1,0 \\
\hline L. do Céu & 25 & $3 / 5$ & 1,0 & $1 / 5$ & 1,0 \\
\hline L. Madame Vinous & 25 & $0 / 5$ & 0 & $0 / 5$ & 0 \\
\hline L. Baianinha & ambiente & $0 / 5$ & 0 & $0 / 5$ & 0 \\
\hline L. do Cesu & ambiente & $0 / 5$ & 0 & $0 / 5$ & 0 \\
\hline L. Madame Vinous & ambiente & $0 / 5$ & 0 & $0 / 5$ & 0 \\
\hline
\end{tabular}

a plantas doadoras de inóculo.

b Notas 1, 2 e 3 correspondem a sintonas fracos, médios e fortes da sorose, respectivamente. 
Tabela 2. Efeito de diferentes temperaturas na manifestaça e intensidade de sintomas da sorose na segunda brotação de tress indicadoras de laranja doce inoculadas com duas fontes do vi rus.

\begin{tabular}{|c|c|c|c|c|c|}
\hline \multirow[b]{2}{*}{ Indicadoras } & \multirow[b]{2}{*}{$\begin{array}{c}\text { Temperatura } \\
\text { de } \\
\text { exposigão } \\
(\cdot C)\end{array}$} & \multirow{2}{*}{\multicolumn{2}{|c|}{$\begin{array}{lc}\frac{\text { Laranja Natal }}{a} \\
\text { No de } & \text { Nota } \\
\text { plantas media } \\
\text { c/sint. Ce de } \\
\text { inoc. Sintomas }\end{array}$}} & \multirow{2}{*}{\multicolumn{2}{|c|}{$\begin{array}{l}\text { L. Folha Murcha } \\
\text { No de Nota } \\
\text { plantas média } \\
\text { c/sint. de } \\
\text { inoc. Sintomas }\end{array}$}} \\
\hline & & & & & \\
\hline L. Baianintia & 15 & $5 / 5$ & 3,0 & $5 / 5$ & 2,0 \\
\hline L. do cesu & 15 & $5 / 5$ & 2,6 & $5 / 5$ & 1,8 \\
\hline L. Madame Vincus & 15 & $5 / 5$ & 2,0 & $5 / 5$ & 1,2 \\
\hline L. Baianinha & 20 & $5 / 5$ & 1,8 & $5 / 5$ & 1,2 \\
\hline L. do Céu & 20 & $5 / 5$ & 1,8 & $4 / 5$ & 1,0 \\
\hline L. Madame Vinous & 20 & $4 / 5$ & 1,0 & $2 / 5$ & 1,0 \\
\hline L. Baianinha & 25 & $2 / 5$ & 1,0 & $2 / 5$ & 1,0 \\
\hline L. do céu & 25 & $3 / 5$ & 1,0 & $2 / 5$ & 1,0 \\
\hline L. Madame Vinous & 25 & $0 / 5$ & 0 & $0 / 5$ & 0 \\
\hline L. Baianinha & ambiente & $0 / 5$ & 0 & $0 / 5$ & 0 \\
\hline L. do Cesu & embiente & $0 / 5$ & 0 & $0 / 5$ & 0 \\
\hline L. Madame Vinous & ambiente & $0 / 5$ & 0 & $0 / 5$ & 0 \\
\hline
\end{tabular}

a Plantas doadoras de inóculo.

b Notas 1, 2 e 3 correspondem a sintomas fracos, medios e fortes da sorose, respectivamente. 
Tabela 3. Número medio de dias entre o infcio do tratamento térmico e o aparecimento de sintomas da sorose na primeira brotação de trés indicadoras de laranja doce inoculada com duas fontes do ví rus após exposição às temperaturas indicadas.

\begin{tabular}{|c|c|c|c|c|}
\hline \multirow{2}{*}{ Indicadora } & \multirow{2}{*}{$\begin{array}{l}\text { Temperatura } \\
\text { de exposição } \\
\qquad(\circ \mathrm{C})\end{array}$} & \multicolumn{3}{|c|}{$\begin{array}{l}\text { No médio de dias para } \\
\text { manifestaçao de sintomas }\end{array}$} \\
\hline & & Laranja Natal & L. Folna & Murcha \\
\hline L. Baianinha & 15 & 3 & & 5 \\
\hline L. do cesu & 15 & 3 & & 5 \\
\hline L. Madame Vinous & 15 & 6 & & 6 \\
\hline L. Baianinha & 20 & 5 & & 5 \\
\hline L. do Cesu & 20 & 6 & & 6 \\
\hline L. Madame Vinous & 20 & 7 & & 8 \\
\hline L. Baianinha & 25 & 6 & & 7 \\
\hline L. do Céu & 25 & 6 & & 7 \\
\hline L. Madame Vinous & 25 & - & & - \\
\hline L. Baianinha & anbiente & - & & - \\
\hline L. do Cesu & ambiente & - & & - \\
\hline L. Madame Vinous & ambiente & - & . & - \\
\hline
\end{tabular}

a Periodo entre a data de exposição das plantas às temperaturas indicadas e o aparecimento de sintomas.

blantas fornecedoras de insculo. 
Tabela 4. Número médio de dias entre o ind cio do tratamento térmico e o aparecimento de sintomas da sorose na segunda brotação de três indicadoras de laranja doce inoculada com duas fontes do virus após exposição às temperaturas indicadas.

\begin{tabular}{|c|c|c|c|c|}
\hline \multirow{2}{*}{ Indicadora } & \multirow{2}{*}{$\begin{array}{l}\text { Temperatura } \\
\text { de exposiçăo } \\
(\circ \mathrm{C})\end{array}$} & \multicolumn{3}{|c|}{$\begin{array}{l}\text { No médio de dias para } \\
\text { manifestação de sintomas }\end{array}$} \\
\hline & & Laranja Natal b & L. Foltha & Murcha \\
\hline L. Baianinha & 15 & 3 & & 4 \\
\hline L. do Cesu & 15 & 3 & & 4 \\
\hline L. Madame Vinous & 15 & 5 & & 6 \\
\hline L. Baianinha & .20 & 5 & & 5 \\
\hline L. do Cêu & 20 & 6 & & 5 \\
\hline L. Madame Vinous & 20 & 6 & & 8 \\
\hline L. Baianinha & 25 & 7 & & 7 \\
\hline L. do céu & 25 & 6 & & 6 \\
\hline L. Madame Vinous & 25 & - & & - \\
\hline L. Baianinha & ambiente & - & & - \\
\hline L. do Céu & ambiente & - & & - \\
\hline L. Madame Vinous & ambiente & - & . & - \\
\hline
\end{tabular}

a Periodo entre a data de exposição das plantas as temperaturas indicadas e o aparecimento de sintomas.

b plantas fornecedoras de inóculo. 
4.1.3. Submetida à temperatura de $25^{\circ} \mathrm{C}$

Com a temperatura de $25 \circ \mathrm{C}$, na primeira brotaçăo com inóculo de laranja 'Natal', apenas 60\% das plantas apresentaram sintomas foliares e na segunda brotação com este mesmo infculo, $40 \%$ das plantas apresentaram folhas com sintomas. Com o isolado procedente da laranja Folha Murcha', 40\% das plantas apresentaram sintomas na primeira e segunda brotação (Tabelas 1 e 2). Bs controles sadios não apresentaram sintomas. A nota média dos sintomas foi de 1,3 e 1,0 com o inóculo procedente da laranja 'Natal' na primeira e segunda brotaçăo respectivamente e nota média 1,0 nas duas brotaçôes com o ináculo procedente da laranja 'FoItha Murcha' (Tabelas 1 e 2). O número de dias entre o incio do tratamento térmico e o aparecimento de sintomas, foi de 6 dias na primeira brotação e 7 dias na segunda quando inoculada com isolado da laranja 'Natal' e 7 dias na primeira e segunda brotação quando inoculada com o isolado da laranja 'Folha Murcha' (Tabelas 3 e 4).

\subsubsection{Mantida em temperatura ambiente}

A indicadora 'Baianintia' também inoculada com isolado da laranja 'Natal' e 'Folha Murcha', quando mantida em casa de vegetaçăo com temperatura variando entre $25,2 \circ \mathrm{C}$ (média mínima) a $35,1 \circ \mathrm{C}$ (média máxima), sendo a temperatura 
média, no período, de aproximadamente $30 \circ \mathrm{C}$, durante a primeira brotaçăo ocorrida em fevereiro de 1991; e 24,3 a 33,7•C (temperatura média mínima e máxima respectivamente), sendo a temperatura média, no perído, de $29 \circ \mathrm{C}$ durante a segunda brotação, ocorrida no mês de abril de 1991, não apresentou sintomas foliares, assim como, os controles sadios não inoculados.

\section{2. Laranja "do céu" inoculada com duas fontes da sorose}

4.2.1. Submetida à temperatura de $15^{\circ} \mathrm{C}$

Quando submetida ao choque térmico de $15 \circ \mathrm{C}$, a laranja 'do Céu' utilizada como indicadora apresentou 100\% de plantas com sintomas nas folhas, na primeira e segunda brotação, quando inoculadas com isolados da laranja 'Natal' ou 'Folha Murcha' (Tabelas 1 e 2 ). Os controles sadios não apresentaram sintomas. Houve diferenças com esta indicadora quanto intensidade de sintomas, que foi maior na primeira brotação do que na segunda, tanto com o isolado da laranja 'Natal' com o qual recebeu nota media 3,0 na primeira brotação e 2,6 na segunda brotação, como com o isolado da laranja 'Folha Murcha', com o qual recebeu nota média 2,0 na primeira brotação e 1,8 na segunda brotação (Tabelas 1 e 2). 
o intervalo entre o inscio do choque térmico e o aparecimento de sintomas foi de 3 dias tanto para a primeira como para a segunda brotação com o inóculo procedente da laranja 'Natal' e 5 dias para a primeira brotação e 4 dias para a segunda, com o inóculo procedente da laranja 'Folha Murcha' (Tabelas 3 e 4 ).

4.2.2. Submetida à temperatura de $20 \circ \mathrm{C}$

Quando a temperatura utilizada foi de $20 \circ \mathrm{C}$, 80\% das plantas mostraram sintomas na primeira brotação e 100\% na segunda, com o isolado da laranja Natal e 80\% na primeira e segunda brotaçăo, ćom o isolado da laranja 'Folha Murcha. (Tabelas 1 e 2). Os controles sadios não apresentaram sintomas. A nota média dos sintomas foi de 3,0 e 2,6 na primeira e segunda brotação, respectivamente quando - inóculo utilizado foi o isolado da laranja 'Natal' e 2,0 e 1,8 com oisolado da laranja 'Folha Murcha' (Tabelas 1 e 2). o número de dias entre o inicio do tratamento térmico e o aparecimento de sintomas foi de 6 dias na primeira e segunda brotação quando o inóculo utilizado foi o isolado da laranja 'Natal' e b dias na primeira brotação e 5 dias na segunda com o isolado da laranja 'Folha Murcha'. 
4. 2. 3. Submetida à temperatura de $25^{\circ} \mathrm{C}$

Com a temperatura de $25 \circ \mathrm{C}$ apenas $60 \%$ das plantas mostraram sintomas, na primeira e segunda brotaçăo com o inćculo de laranja 'Natal'. Quando o inóculo utilizado foi o isolado da laranja 'Folha Murcha', somente $20 \%$ das plantas inoculadas mostraram sintomas na primeira brotaçăo, sendo que na segunda brotação a porcentagem de plantas inoculadas que mostraram sintomas foi de $40 \%$. Os controles sadios năo apresentaram sintomas. A nota média dos sintomas foi 1, o na primeira e sequnda brotaçăo, quando utilizado o isolado da laranja 'Natal' e da laranja 'Folha Murcha' TTabelas 1 e 2). O número de dias entre o início do tratamento térmico e a aparecimento de sintomas foi de $b$ dias na primeira e segunda brotaça quanto o ismado utilizanto foi da laranja 'Natal' e de 7 dias na primeira brotaçăo e 6 dias na segunda com o isolado da laranja 'Folha Murcha'.

\subsection{Mantida em temperatura ambiente}

Em casa de vegetaçăo, na temperatura media jă descrita anteriormente, nenhuma planta apresentou sintomas, tanto quando foi utilizado isolado da laranja 'Natal' ou da laranja 'Folha Murcha', no mesmo periodo, assim como os controles sadios. 


\section{3. Laranja "Madame Vinous" inoculada com duas fontes da sorose}

4.3.1. Submetida à temperatura de $15^{\circ} \mathrm{C}$

A laranja 'Madame Vinous', também utilizada como indicadora neste trabalho, quando submetida ao choque térmico de $15 \circ \mathrm{C}$ apresentou $100 \%$ de plantas com sintomas foliares na primeira e segunda brotaçăo, quando inoculadas com isolados da laranja 'Natal' e 80\% de plantas com folhas com sintomas na primeira brotação e $100 \%$ de plantas com folhas com sintomas na segunda brotaçăo, com o isolado da laranja 'Folha Murcha' (Tabelas 1 e 2). Os controles sadios năo apresentaram sintomas. A intensidade de sintomas foi maior na primeira brotação do que na sergunda, tanto com o isolado de Iaranja 'Natal' com o qual recebeu nota média 2,2 na primeira brotação e 2,0 na segunda, como com o isolado da laranja 'Folha Murcha' com o qual recebeu nota média 1,5 na primeira brotação e nota média 1,2 na segunda brotação (Tabelas 1 e 2). O número de dias entre o iníio do choque térmico e o aparecimento de sintomas foi de 6 dias na primeira brotação e 5 dias na segunda, com o isolado da laranja 'Natal' e de 6 dias na primeira e segunda brotaçăo, com o isolado da laranja 'Folha Murcha' (Tabelas 3 e 4). 


\title{
4.3.2. Submetida à temperatura de $20^{\circ} \mathrm{C}$
}

\begin{abstract}
Quando as plantas foram submetidas à temperatura de $20^{\circ} \mathrm{C}$, apenas $60 \%$ das plantas inoculadas apresentaram sintomas nas folthas da primeira brotação e $80 \%$ apresentaram sintomas na segunda brotação, quando o inóculo utilizado foi o isolado da laranja 'Natal' e somente $40 \%$ das plantas inoculadas na primeira e segunda brotação apresentaram sintomas nas folhas quando o inóculo utilizado foi o isolado da laranja 'Folha Murcha' (Tabelas 1 e 2). Os controles sadios năo apresentaram sintomas. A nota media recebida foi 1, o na primeira e segunda brotaçăo, com o isolado da laranja 'Natal' e da 'Folha Murcha'. O número de dias entre o início do tratamento termico e o aparecimento de sintomas foi de 7 dias na primeira brotação e $b$ dias na segunda, quando o inóculo utilizado foi o isolado da laranja 'Natal' e de 8 dias tanto na primeira como na segunda brotação, com o isolado da laranja 'Folha Murcha'.
\end{abstract}

4.3.3. Submetida à temperatura de $25^{\circ} \mathrm{C}$

Quando submetida d̀ temperatura de $25^{\circ} \mathrm{C}$, nenhuma das folhas das plantas da indicadora 'Madame Vinous" apresentou sintomas. 


\section{3.4. Mantida em temperatura ambiente}

Em casa de vegetação, na temperatura média já descrita anteriormente esta indicadora não apresentou nenhuma folha com sintomas, tanto quando foi utilizado inóculo procedente da laranja 'Natal', ou da laranja 'Folha Murcha', assim como as controles sadios.

4. 4. Laranja 'Baianinha' enxertada com borbul has de quatro laranjas doces suspeitas de estarem infectadas pela sorose

\section{4.1. Submetida à temperatura de $15^{\circ} \mathrm{C}$}

Esta indicadora apresentou na primeira brotaçă quando submetida ao choque témico de isoc, $0 \%$ de plantas com sintomas quando enxertadas com material de clone velho suspeitos de estarem infetados pelo virus da sorose, das seguintes Variedades: laranja 'Natal', laranja 'Pera' e laranja 'Hamlin', tendo, entretanto, apresentado $100 \%$ de plantas com sintomas em folhas, quando enxertada com o clone velho também suspeito de estar infectado, da variedade laranja 'Valencia' (Tabela 5). As plantas controles sadias; nåo apresentaram sintomas. A nota média dos sintomas apresentados foi 1,6 (Tabela 6). O tempo medio entre o inicio do tratamento térmico e o aparecimento de sintomas foi de 6 dias (Tabela 7). 
Tabela 5. Efeito do choque térmico na manifestaça de sintomas da sorose em quatro indicadoras de laranja doce enxertadas com borbulhas de quatro plantas suspeitas de estarem infetadas com este virus.

\begin{tabular}{|c|c|c|c|c|c|}
\hline \multirow{2}{*}{ Indicadoras } & \multirow{2}{*}{$\begin{array}{l}\text { Temperatura } \\
\text { de } \\
\text { exposição } \\
(\circ \mathrm{C})\end{array}$} & \multicolumn{4}{|c|}{ No de plantas com sintomas/inoculadas } \\
\hline & & Natal ${ }^{a}$ & Pera & Valência & Haml in \\
\hline L. do cesu & 15 & $0 / 5$ & $0 / 5$ & $5 / 5$ & $0 / 5$ \\
\hline L. Baianinha & 15 & $0 / 5$ & $0 / 5$ & $5 / 5$ & $0 / 5$ \\
\hline L. Madame Vinous & 15 & $0 / 5$ & $0 / 5$ & $4 / 5$ & $0 / 5$ \\
\hline L. Caipira & 15 & $0 / 5$ & $0 / 5$ & $5 / 5$ & $0 / 5$ \\
\hline L. do Céu & ambiente & $0 / 5$ & $0 / 5$ & $0 / 5$ & $0 / 5$ \\
\hline L. Baianinta & ambiente & $0 / 5$ & $0 / 5$ & $0 / 5$ & $0 / 5$ \\
\hline L. Madame Vinous & ambiente & $0 / 5$ & $0 / 5$ & $0 / 5$ & $0 / 5$ \\
\hline L. Caipira & ambiente & $0 / 5$ & $0 / 5$ & $0 / 5$ & $0 / 5$ \\
\hline
\end{tabular}

Plantas suspeitas de estarem infetadas com o vi rus da sorose. 
Tabela 6. Efeito do choque térmico na intensidade de sintomas da sorose em quatro indicadoras de laranja doce enxertadas com borbulhas de quatro plantas suspeitas de estarem infetadas com este ví rus.

\begin{tabular}{|c|c|c|c|c|c|}
\hline \multirow{2}{*}{ Indicadoras } & \multirow{2}{*}{$\begin{array}{l}\text { Temperatura } \\
\text { de } \\
\text { exposição } \\
(\cdot \mathrm{C})\end{array}$} & \multicolumn{4}{|c|}{$\begin{array}{c}\text { Nota media dos sintomas apresentados } \\
\text { por } \mathbf{5} \text { plantas }\end{array}$} \\
\hline & & Natal ${ }^{a}$ & Pera & Valência & Haml in \\
\hline L. do Cêu & 15 & 0 & 0 & 1,6 & 0 \\
\hline L. Baianinha & 15 & 0 & 0 & 1,4 & 0 \\
\hline L. Madame Vinous & 15 & 0 & 0 & 1,0 & 0 \\
\hline L. Caipira & 15 & 0 & 0 & 1,0 & 0 \\
\hline L. do Céu & ambiente & 0 & 0 & 0 & 0 \\
\hline L. Baianinha & ambiente & 0 & 0 & 0 & 0 \\
\hline L. Madame Vinous & ambiente & 0 & 0 & 0 & 0 \\
\hline L. Caipira & ambiente & 0 & 0 & 0 & 0 \\
\hline
\end{tabular}

a plantas suspeitas de estaremi infetadas coni o vi rus da sorose. 
Tabela 7. Número médio de dias entre o início do tratamento térmico e o aparecimento de sintomas da sorose en quatro indicadoras de laranja doce, enxertadas com borbulhas de quatro plantas suspeitas de estarem infetadas com este vi rus, submetidas à chogue térmico.

\begin{tabular}{|c|c|c|c|c|c|}
\hline \multirow{2}{*}{ Indicadoras } & \multirow{2}{*}{$\begin{array}{l}\text { Temperatura } \\
\text { de } \\
\text { exposição } \\
\left(\circ^{\circ} \mathrm{C}\right)\end{array}$} & \multicolumn{4}{|c|}{$\begin{array}{c}\text { No medio de dias para manifestaçăo } \\
\text { de sintomas }\end{array}$} \\
\hline & & Natal ${ }^{a}$ & Pera & Valência & Hamlin \\
\hline L. do céu & 15 & - & - & 5 & - \\
\hline L. Baianinha & 15 & - & - & 6 & - \\
\hline L. Madame Vinous & 15 & - & - & 7 & - \\
\hline L. Caipira & 15 & - & - & 6 & - \\
\hline L. do Céu & ambiente & - & $\cdots$ & - & - \\
\hline L. Baianinha & ambiente & - & - & - & - \\
\hline L. Madame Vinous & ambiente & - & - & - & - \\
\hline L. Caipira & ambiente & - & - & - & - \\
\hline
\end{tabular}

a

Plantas suspeitas de estarem infetadas com o virus da sorose. 


\section{4. 2. Mantida em temperatura ambiente}

A indicadora laranja 'Baianinha' mantida em casa de vegetaçăo, cuja temperatura média ambiente no perlodo de 18 a 29 de outubro de 1991 variou de $35^{\circ} \mathrm{C}$ (média máxima) a $23^{\circ} \mathrm{C}$ (média minima), sendo a temperatura média de $29 \circ \mathrm{C}$, inoculada com material de clone velho conforme descrito no item 4.4.1., năo apresentou sintomas em nenhuma das plantas (Tabela 5), o mesmo ocorrendo com os controles sadios.

4.5. Laranja "do Cieu" enxertada com borbul has de quatro laranjas doces suspeitas de estarem infectadas pela sorose

4.5.1. Submetida à temperatura de $15^{\circ} \mathrm{C}$

A laranja 'do Cé, utilizada como indicadora e submetida ao choque térmico de $15^{\circ} \mathrm{C}$, inoculada com material de clone velho suspeitos de estarem infectados pelo vírus da sorose, apresentou $0 \%$ de plantas com sintomas, quando enxertada com a laranja" 'Natal', laranja 'Pera' e laranja 'Hamlin'. Quando o material suspeito a ser testado, foi a laranja 'Valéncia', houve 100\% de plantas com sintomas em folhas da indicadora (Tabela 5). As plantas controles sadias não apresentaram sintomas. A ṇota média dos sintomas 
apresentados foi 1,6 (Tabela 6). 0 número médio de dias entre o inficio do tratamento térmico e o aparecimento de sintomas foi de 5 dias (Tabela 7 ).

\title{
4.5.2. Mantida em temperatura ambiente
}

A indicadora laranja 'do Céu' mantida em casa de vegetação, na temperatura média já descrita anteriormente, enxertada com material de clone velho suspeito de estar infectado pelo vírus da sorose, também descrito anteriormente, não apresentou sintomas em nenhuma das plantas (Tabela 5), o mesmo ocorrendo com os controles sadios.

\subsection{Laranja 'Madame Vinous' enxertada com borbul has de quatro laranjas doces suspeitas de estarem infectadas pela sorose}

4.6.1. Submetida à temperatura de $15^{\circ} \mathrm{C}$.

\begin{abstract}
A indicadora laranja 'Madame Vinous' quando submetida ao choque térmico de $15 \circ \mathrm{C}$, também apresentou $0 \%$ de plantas com sintomas nas folhas quando enxertada com material de clone velho suspeitos de estarem infetados pelo virus da sorose, das seguintes variedades: laranja 'Natal', laranja 'Pera' e laranja 'Hamlin'; apresentou no entanto 80\% de plantas com sintomas em folhas, quando enxertada com o
\end{abstract}


clone velho de laranja 'Valencia' (Tabela 5). As plantas controles sadias não apresentaram sintomas. A nota média dos sintomas apresentados foi 1,0 (Tabela 6). O tempo médio entre o inlcio do tratamento térmico e o aparecimento de sintomas foi de 7 dias (Tabela 7 ).

4. 6. 2. Mantida em temperatura ambiente

A indicadora laranja 'Madame Vinous' mantida em casa de vegetação, na temperatura média já descrita anteriormente, enxertada com material de clone velho conforme descrito no item 4.4.1, nåo apresentou sintomas em nenhuma das plantas (Tabela 5), o mesmo ocorrendo com os controles sadios.

4.7. Laranja 'Caipira' enxertada com borbul has de quatro laranjas doces suspeitas de estarem infectadas pela sorose

4.7.1. Submetida d̀ temperatura de $15^{\circ} \mathrm{C}$

Esta indicadora quando submetida ao choque térmico de $15 \circ \mathrm{C}$, também apresentou $0 \%$ de plantas com sintomas nas folhas, quando enxertada com material de clone velho das seguintes variedades: laranja 'Natal', laranja 'Pera' e laranja 'Hamlin' e 100\% de plantas com sintomas em folhas quando enxertada com a laranja 'Valencia' (Tabela 5). 
As plantas controles 5 adias nåo apresentaram sintomas. A nota média dos sintomas apresentados foi 1,0 (Tabela 6). 0 tempo médio entre o inscio do tratamento térmico e o aparecimento de sintomas foi de 6 dias (Tabela 7).

\subsubsection{Mantida em temperatura ambiente}

A indicadora laranja 'Caipira' mantida em casa de vegetaçăo, na temperatura média já descrita anteriormente, também enxertada com material de clone velho conforme descrito no item 4.4.1, nåo apresentou sintomas em nentiuma das plantas (Tabela 5), sendo o mesmo resultado também obtido com os controles sadios. 


\title{
5. DISCUSSÃ̃
}

\begin{abstract}
Nos palses de climas subtropicais ou mediterráneos como os Estados Unidos, Espantia, Itália e outros, a sintomatologia foliar da sorose dos citros é de fácil visualização nos pomares ou em plantas de casa de vegetaçăo. Já em regiß̧es com climas tropicais, a observação dos sintomas no campo ou em casa de vegetação é praticamente impossivel durante todo o ano, devido as elevadas temperaturas prevalentes, como no caso da Venezuela e Nordeste brasileiro. Em regizes de clima tropical de altitude, como é - caso do Estado de São Paulo, somente na brotação de primavera que se desenvolve em temperatura amena $( \pm 20 \circ \mathrm{C})$ é que os sintomas foliares da sorose são observáveis.
\end{abstract}

No presente trabalio ficou bem patente o efeito da temperatura na expressão de sintomas do virus da sorose em folhas de plantas indicadoras. Demonstrou-se experimentalmente que temperaturas na faixa de 29 a $30 \circ \mathrm{C}$ são inadequadas à manifestação de sintomas foliares da sorose. Apenas as indicadoras mais sensiveis apresentaram sintomas fracos à $25 \circ \mathrm{C}$. Com a temperatura a $20^{\circ} \mathrm{C}$, a maioria das plan- 
tas apresentou sintomas foliares classificados como médios, exceto a laranja.'Madame Vinous' que, embora seja muito utilizada em diversos palses, como indicadora bastante sensivel, neste experimento apresentou sintomas fracos. Com o choque térmico a $15^{\circ} \mathrm{C}$, os sintomas foliares foram fortes na laranja 'Baianinha' e 'do Céu' e médio na 'Madame Vinous' (Tabelas 1 e 2). O fato da 'Madame Vinous' nå apresentar sintomas a $25 \circ \mathrm{C}$, apresentar sintoma fraco a $20 \circ \mathrm{C}$ e médio a 15०C, pode ser devido a luminosidade da cámara de crescimento, inadequada a esta indicadora ou mais provavelmente, à sua menor sensibilidade.

Os resultados mostraram que quanto mais baixa foi a temperatura, maior foi a intensidade de sintoma nas folhas das indicadoras. Seria de se esperar que em temperatura ainda mais baixas, as sintomas fossem se acentuando. Entretanto, é sabido que temperaturas na faixa de 12 a 13.C podem paralizar o crescimento das plantas citricas (REUTHER, 1973). Esse é o principal motivo da escolna de $15 \circ$ C como a temperatura mais baixa neste experimento.

Embora os resultados obtidos no primeiro e segundo experimentos apontem a baixa temperatura como principal fator de manifestaça de sintomas em folhas das plantas indicadoras para o vírus da sorose, nåo houve como concluir se a baixa temperatura age sobre o virus, aumentando a sua concentração e consequentemente a manifestação de sintomas, ou, se tem um efeito sobre a planta predispondo-a, 
tornando-a mais sensivel, ou, ainda se atua na interação de ambos. Investigaçð̋es neste sentido são importantes, entretanto no presente dificeis de serem realizadas, uma vez que - vIrus da sorose A não foi totalmente caracterizado.

o efeito da baixa temperatura na manifestaçăo de sintomas é importante não só para a sorose dos citros, mas também, para outras viroses em culturas de importancia no pals. Assim, KUNIYUKI (1988) trabalhando com o vírus do mosaico das nervuras da videira, observou que os sintomas em plantas indicadoras mesmo fora de casa de vegetaçăo, năo se tornavam visiveis ou apareciam em poucas plantas, durante periodos prolongados de muito calor. 0 autor interpretou que, nestes periodos, as folhas jovens logo tornam-se rigidas e amareladas, principalmente nas plantas não bem estabelecidas em vasos ou mesmo no solo, impossibilitando a observação de sintomas. Menciona o autor, que experimentalmente, năo é tarefa fácil demonstrar esse fato, mas, julga bastante provável, que assim seja, pois sintomas podem se manifestar em plantas de crescimento vigoroso mesmo no verão, quando sobrevem um periodo de temperatura amena. Conclui que a ocorrência de sintomas na brotação de primavera quando a temperatura está amena $( \pm 20 \circ \mathrm{C})$ era devido possivelmente ao fato das folhas permanecerem sob condiça jovem por um periodo de tempo maior. Esta conclusão é bastante razoável uma vez que nas plantas cltricas deste experimento com o virus da sorose observou-se o mesmo fato. 
Apesar de investigaçชes visando demonstrar o efeito da baixa temperatura na manifestação de sintomas em folhas de plantas indicadoras para o virus da sorose não te rem sido feitas, encontramos na literatura um trabalio bastante interessante, mostrando o efeito da baixa temperatura na expressão de sintomas, relacionando-a com a concentração de virus na cultura do melão. Este trabaliho foi realizado por FOSTER \& WEBB (1965), inoculando seis virus individualmente em plantas jovens de melão (Cucumis melo $\mathrm{L}$. var. reticulatus Naud, cV. PMR 45). Os virus utilizados foram: virus do mosaico da melancia-1, atualmente denominado virus do mosaico do mamoeiro-estirpe melancia ("Papaya ringspot virus - type W"; virus do mosaico da melancia-2 ("Watermelon mosaic virus-2"); virus do mosaico da abobora ("Squash mosaic virus"); virus do mosaico do pepino ("Cucumber mosaic virus"); virus latente das cucurbitáceas ("Cucurbit latent virus"), virus da necrose estriada do melăo ("Muskmelon necrotic fleck virus"). As plantas inoculadas com estes virus, foram submetidas a tres diferentes temperaturas constantes: de 18,$3 ; 29,4$ e $40,6 \circ \mathrm{C}$. Entre quarenta e quarenta e oito dias após a inoculação, amostras de folhas jovens foram retiradas para verificação da concentração dos virus. Através dos resultados obtidos, os autores concluiram que a temperatura é mais importante para a planta do que para o virus, uma vez que as melhores expressชes de sintomas foram obtidas na temperatura de 
$18,3 \circ C$ para cinco dos seis virus estudados, sendo que, com o virus latente das cucurbitáceas năo apareceram sintomas em nenhuma das plantas e a concentração dos víus variaram de virus para virus, nas trés temperaturas estudadas. Neste trabalino, os autores demonstraram portanto, não haver correlaçăo entre a maior ou menor concentraçăo do vírus com a intensidade de sintomas, e sim a temperatura predispondo a planta ao efeito do virus, o que pode tambem ser verdadeiro no caso da sorose dos citros.

Além da temperatura, a planta indicadora e o isolado do virus são fatores que determinam a intensidade de sintomas, conforme pode ser verificado nos resultados deste experimento (Tabelas 1, 2 e 6).

No caso do presente trabaliho, as laranjas doces 'Baianinha' $e$ 'do Csu' comportaram-se como indicadoras mais sensiveis quando comparadas com a laranja 'Caipira' e 'Madame Vinous', pois apresentaram manifestaçōes e intensidade de sintomas superiores a estas outras duas indicadoras (Tabelas 1, 2, 5 e 6). Quanto aos isolados do vírus da sorose, estes devem fazer parte de um complexo, que contém variantes que causam sintomas mais fortes ou mais fracos podendo este fato.ser constatado nos resultados do primeiro e segundo experimento, nos quais a mesma indicadora submetida a mesma temperatura, inoculada com isolados retirados de várias plantas, apresentaram intensidades de sintomas diferentes (Tabela 1, 2 e 6). 


\title{
6. CONCLUSOES
}

\author{
Os resultados do presente trabalho permitem \\ que sejam tiradas as seguintes conclusరes:
}

- a temperatura é um fator primordial na manifestação de sintomas foliares em plantas indicadoras inoculadas com o virus da sorose dos citros;

- o choque termico de $15 \circ \mathrm{C}$ durante um período de 3 a 6 dias mostrou-se o mais adequado para manifestação de sintomas;

- as laranjas doces 'Baianinha' e 'do Céu' são indicadoras bastantes sensiveis para testes de indexação biológica para o vírus da sorose, desde que submetidas ao choque térmico acima;

- A origem do isolado do vírus da sorose influenciou na intensidade de sintomas, nas condiçós do presente trabaliho; 
- testes de indexação biologica para o virus da sorose nas condiçŏes de Săo Paulo podem também ser realizadas nas épocas quente do ano, desde que as plantas indicadoras sejam submetidas a choque térmico. 


\section{REFERÊNCIAS BIBLIOGRÁFICAS}

BEAATENA, H.N.; PORTILLO, M.M. Natural spread of psorosis in sweet orange, seedlings. In: GARNSEY, S.M.; TIMMER, L.W.; DODDS, J.A. (ed.). Proc. 9th Conf. Inter. Organ. Citrus Virol. pp.159-64. Univ. California Press, Riverside, Califórnia, 1984.

BITANCOURT, A.A. Relação das doenças e fungos parasitas observados na Seção de Fitopatologia durante os anos de 1931 a 1932. Arquivos do Instituto Biológico, 5: 185-96, 1934.

BRIDGES, G.D.; YOUTSEY, C.0.; NIXON Jr., R.R. Observations indicating psorosis transmission by seed of Carrizo citrange. Proc. Fla. State Hortic. Soc., 78: 48-50, 1965.

CALAVAN, E.C.; MATHER, S.M.; ME EACHERN, E.H. Registration, Certification, and indexing of citrus trees, p.185-222. In: W. REUTHER, E.C. CALAVAN, G.E. CARMAN (eds.). The Citrus Industry, Vol. IV. Univ. Cal. Div. Agric. Sci. Berkeley, Califórnia, 1978.

CALVERT, L.A.; LEE, R.F.; HIEBERT, E. Complementary DNA cloning of Citrus variegation virus characterization of the RNA species with these probes. In: Abstracts the 10th Conf. IOCV. p.114, Spain, 1986. 
CAMPIGLIA, H.G.; SILVEIRA, C.M.; SALIBE, A.A. Psorosis transmission through seeds of trifoliate orange. p.132-4. In: Proc. 7th Conf. IOCV Univ. Calif., Riverside, 1976:

CHIARAPPA, L. A World Wide list of Virus-Indexed Propagating Material - Section II: Citrus. P.52. Plant Production and Protection-Division. Food and Agriculture Organization of the United Nations. Rome, 1966.

FAWCETT, H.S. New angles on treatment of bark diseases of citrus. California Citrograph., 17: 406-8, 1932.

FAWCETT, H.S. NeW symptoms of psorosis indicating a virus disease of Citrus. Phytopathology, 23: 930, 1933.

FAWCETT, H.S. Is psorosis of citrus a virus disease? Phytopathology, 24: 659-68, 1934.

FAWCETT, H.S. Citrus diseases and their control. McGraw Hill Book Co., Inc., New York and London, 1936. 656p.

FAWCETT, H.S.; GRILLO, H.V.S.; BITANCOURT, A.A.; MULLER, A.S. Relatório sobre as doenças dos citrus no Distrito Federal, Estado do Rio de Janeiro e Minas Gerais. Rodriguésia, 2: 329-344, 1936.

FAWCETT, H.S. \& BITANCOURT, A.A. Relatorio sobre as doenças dos citrus nos Estados de Pernambuco, Bahia, Săo Paulo e Rio Grande do Sul. Rodriguésia, 10: 213-36, 1937.

FAWCETT, H.S. \& BITANCOURT, A.A. Comparative symptomatology of psorosis varieties on Citrus in California. Phytopathology, 33: 847-64, 1943. 
FAWCETT, H.S. \& KLOTZ, L.J. Types and symptoms of psorosislike diseases of Citrus. Phytopathology, 28: 670, 1938.

FAWCETT, H.S. \& KLOTZ, L.J. Infections variegation of Citrus. Phytopathology, 29: 911-2, 1939.

FAWCETT, H.S. \& KLOTZ, L.J. Diseases and their control. Cap. XI. PP.495-596. In: L.D. BATCHELOR \& H.J. WEBBER (eds.). The Citrus Industry, v.II. University of California Press,, Berkeley and Los Angeles, 1948.

FOSTER, R.E. \& WEBB, R.E. Temperature effects on symptom expression and concentration of six muskmelon viruses. Phytopathology, 55: 981-5, 1965.

GARCIA, M.L.; ARRESE, E.L.; GRAU, 0.; SARACHU, A.N. Citrus psorosis disease agent behaves as a two component SSRNA virus. PP.337-344. In: BRLANSKY, R.H.; LEE, R.F.; TIMMER, L.W.(eds.). Proc. of the 11 th Conf. of the Intern. Organization Citrus Virol. Univ. of California, Riverside, 1991.

GARNSEY, S.M. Purification and serology of a Florida isolate of citrus variegation virus. pp.169-75. In: 6th Conf. IOCV Univ. Calif. Dir. Agr. Sci., Richmond, 1974.

GRANT, T.J. Effect of heat treatment on tristeza and psorosis viruses in citrus. Plant Dis. Reptr., 41(4): $232-4,1957$.

GUIRADO, N.; MÜlleR, G.W.; BETTI, J.A.; PRATES, H.S. Manifestaçăo rápida de sintomas foliares do virus da sorose dos citros em ambiente refrigerado. Fitopatologia Brasileira, 11: 336, 1986a. 
Guirado, N.; MülleER, G.W.; PRATES, H.S.; BETTI, J.A.; ARRUDA, H.B. Avaliação de 7 variedades de laranja doce e 2 tangerinas como indicadoras para o virus da sorose dos citros. Summa Phytopathologica, 12: 30, $1986 b$.

KUNIYUKI, H. VIrus do mosaico das nervuras da videira no Estado de 5ão Paulo. Piracicaba, 1988. 96p. (Doutorado - Escola Superior de Agricultura "Luiz de Queiroz"/ USP).

LAROCCA, L.H. La citricultura en la provincia de Entre Rios. Actas Jornadas Técnicas XVI Fiesta Nacional de $1 a$ Citricultura. INTA, 1984. P.42-51.

LEE, H.A. Califórnia scaly bark and bark rot of citrus trees in Phylippines. Philippine Agr. Rev., 16: 219-25, 1923.

LEVY, L. \& GUMPF, D.J. Studies on the psorosis disease of a flexuous virus associated with the disease. p.319-36. In: BRLANSKY, R.H.; LEE, R.F.; TIMMER, L.W. (eds.). Proc. of the 11 th Conf. of the Intern. Organization Citrus Virol. Univ. of California, Riverside, 1991.

MALAGUTI, G. \& KNORR, L.C. Psorosis in Veriezuela. An emendation. p.57-9. In: W.C. PRICE (ed.). Proc. and Conf. Intern. Organization Citrus Virol. Univ. Fla. Press Gainesville, 1961.

MALAGUTI, G. \& STONER, W.N. Psorosis de las citricas em venezuela. Agron. Trop., Maracay, 4(3): 127-49, 1954. 
MONTEVERDE, E.; DELGADO, L.; RUIZ, J.R.; ESPINOZA, M. Sintomatologia del virus de la Psorosis en el Cultivar de Naranja "Hamlin" (Citrus sinensis (L.) Osbeck) Bajo condiciones controladas en cåmara de crecimiento. Associacion Latinoamericana de Fitopatologia, 15(1): 73-7, 1980 .

PASSOS, 0.S. Absence of young-leaf symptoms of psorosis in the State of Bahia, Brazil. p.167-9. In: W.C. PRICE (ed.). Proc. 3th Conf. Intern. Organization Citrus Virol. Univ. Florida Press, Gainesville, 1965.

PASSOS, O.S.; COELHO, Y.S.; PINTO DA CUNHA SOBRINHO, A. More information on psorosis disease in Bahia, Brazil. In: WEATRHERS, L.G.; COHEN, M. (eds.). Proc. 6th Conf. IOCV. University of California, Riverside, p.135-8, 1974.

PRICE, W.C. Translocation of tristeza and psorosis viruses. In: CHILDS, J.F.L. (ed.). Proc. 4th Conf. Intern. Organ. Citrus Virol. 0.52-8. Univ. Florida Press, Gainesville, 1968.

PUJOL, A.R. Transmissión de Psorosis atráves de la semilha de Citrange Troyer, INTA, Cent. Reg. Entrerriano Ser. Téc. No $10: 1-7,1966$.

REUTHER, W. Climate and citrus behavior. In: The citrus Industry. Univ. of California, vol. 3, p.280-337, 1973.

ROISTACHER, C.N. Detection of Citrus Viruses by Graft transmission: A Review. pp.175-84. In: Proc. 7th Conf. IOCV, Riverside, 1976. 
ROISTACHER, C.N. \& BLUE, R.L. A psorosis like virus causing symptoms only on Dweet tangor. In: CHILDS, J.F.L: (ed.). Proc. 4th Conf. Intern. Organ. Citrus Virol., p.13-8. Univ. Fla. press, Gainesville, Fla. 1968.

ROISTACHER, C.N. \& NAUER, E.M. A comparison of certain sweet orange varieties as indicators for concave gum and psorosis viruses. Plant Dis. Reptr., 48: 56-9, 1964.

SWINGLE, W.T. \& WEBBER, H.J. The principal diseases of citrus fruits in Florida, U.S. Dept. Agr. Div. Veg. Phys. \& Path. Bull, 8: $1-42,1896$.

UYEDA, I. \& MINK, G.I. Relationship among some ilarviruses: Proposed revision of subgroup A. Phytopathology, 73: 4750, 1983.

WALLACE, 3.M. Technique for hastening foliage symptoms of psorosis of citrus. Phytopathology, 35: 535-41, 1945.

WALLACE, J.M. Virus-strain interference in relation to symptoms of psorosis disease of citrus. Hilgardia, 27: $223-46,1957$.

WALLACE, J.M. Psorosis A, blind pocket, concave gum, crinkly leaf, and infectious variegation. In: CHILDS, J.F.L. (ed.). Indexing procedures for 15 virus diseases of citrus tress, pp.5-15. U.S. Dept. Agr. Res. Serv., Agr. Handbook 333. Washington, D.C., 1968. 